\title{
Managing inequality: the political ecology of a small-scale fishery, Mweru-Luapula, Zambia
}

\author{
Bram Verelst ${ }^{1}$ \\ University of Ghent, Belgium
}

\section{Introduction}

Many scholars assume that most small-scale inland fishery communities represent the poorest sections of rural societies (Béné 2003). This claim is often argued through what Béné calls the "old paradigm" on poverty in inland fisheries: poverty is associated with natural factors including the ecological effects of high catch rates and exploitation levels. The view of inland fishing communities as the "poorest of the poorest" does not imply directly that fishing automatically lead to poverty, but it is linked to the nature of many inland fishing areas as a common-pool resources (CPRs) (Gordon 2005). According to this paradigm, a common and open-access property resource is incapable of sustaining increasing exploitation levels caused by horizontal effects (e.g. population pressure) and vertical intensification (e.g. technological improvement) (Brox 1990 in Jul-Larsen et al. 2003; Kapasa, Malasha and Wilson 2005).

The gradual exhaustion of fisheries due to "Malthusian" overfishing was identified by H. Scott Gordon (1954) and called the "tragedy of the commons" by Hardin (1968). This influential model explains that whenever individuals use a resource in common - without any form of regulation or restriction - this will inevitably lead to its environmental degradation. This link is exemplified by the prisoner's dilemma game where individual actors, by rationally following their self-interest, will eventually deplete a shared resource, which is ultimately against the interest of each actor involved (Haller and Merten 2008; Ostrom 1990). Summarized, the model argues that the open-access nature of a fisheries resource will unavoidably lead to its overexploitation (Kraan 2011).

The paradigm of Malthusian overfishing is related to poverty in two ways. Firstly, it explains population pressure and increasing fishing efforts through seeing small-scale fishing as a last-resort activity, where a larger socioeconomic or political context pushes people into fishing activities (Béné 2003, 2009; Onyango 2011; Smith, Koa and Lorenzen 2005). Increasing population pressure then has negative impacts on the level of fish stocks, which in turn contribute to further impoverishment of the fishermen (Agrawal 2005). Overexploitation will only increase as fishermen's incomes decrease (Kraan 2011).

These presumptions argue for an "external Leviathan" to control and regulate shared natural resources and have therefore historically legitimized governmental management intervention (Jentoft et al. 2009; Ostrom 1990). As Haller (2007:1) explained, the model of the tragedy of the commons "seems to have encouraged many governments in the South to take rights and responsibilities related to resources out of the hands of local groups and to legitimize this by claiming that the overuse of CPRs such as forests, wildlife, fisheries and pastures was the result of this tragedy."

It is widely acknowledged, however, that conventional centralized management of natural resources has failed to improve resource development, due to a lack of enforcement capacity and insufficient legitimacy at the local level to ensure compliance with regulation measures (Andrew and Evans 2011; Jul-Larsen and Van Zwieten 2002). This realization has led to a shift from a centralized management approach to fishery resources, to decentralized approaches where locally based institutional systems are included, and participation at community level is promoted (Haller 2007; Jul-Larsen and Van Zwieten 2002). This decentralization process has been recommended by international organizations including the World Bank and the UN Food and Agriculture Organization (FAO) in order to address the issue of resource overexploitation. Thus opportunities have been created to implement co-management regimes, which include partnership arrangements and power-sharing models that can instruct local communities but also transfer effective control by delegating power to the community level (Pomeroy, Cinner and Raekjaer 2011).

Every resource management approach is an application of environmental knowledge. This means governance is composed of understandings of "human societies and the environment, scientific findings and technologies, standard (accepted) management approaches, political and economic prerogatives, and locationspecific understandings" (Goldman and Turner 2011: 2). At the same time, the body of environmental

\footnotetext{
${ }^{1}$ Bram Verelst, Master in Science of Conflict and Development, Department of Third World Studies, Faculty of Political and Social Sciences, Ghent University, Universiteitstraat 8, 9000 Ghent, Belgium. Email: bramverelst "at" gmail.com.

I acknowledge the support of VLIR-UOS for funding two months of fieldwork in Zambia and the support of the Department of Fisheries and PLARD (Programme for Luapula Agricultural and Rural Development). I benefited from discussions with Prof. Anne Walraet during the early part of this research. I want to acknowledge with special gratitude and appreciation Dr. Simon Heck, for the promotion and guidance of my research in Zambia, and for his warmth and hospitality. Many thanks to the people of WorldFish Center Lusaka - in particular Margareth, Elias, Angela and Saskia for the practical assistance and for making me feel at home. Special appreciation goes to Justin, for accompanying me during my interviews, for facilitating my research, and for being a friend who I will always carry in my heart.
} 
knowledge that shapes resource management has been widely criticized for prioritising environmental sustainability over social and economic concerns (Hauck 2011). However, poverty also means that there is a direct relationship between low fishermen's incomes - due to low catch - and overexploitation of resources (as a result of the open-access nature of fisheries) (Kraan 2011).

Many scholars therefore argue for the inclusion of issues of power and ideology - essential elements to understand social and institutional change - in fisheries management (Béné 2003; Haller and Merten 2008; Jentoft 2011). The complexities of politics and social interactions cannot and may not be ignored in the governance of resources (Agrawal 2005). Building on these criticisms, this article analyzes in what way the environmental knowledge base that constitutes fisheries (co-)management in Mweru-Luapula, Zambia, corresponds to the political ecology of the Mweru-Luapula fishing economy itself. The historical trajectories of both the governance and the socioeconomic structures of Mweru's fisheries will therefore be investigated simultaneously.

\section{Theoretical elaboration: the arguments}

The knowledge base around which Mweru-Luapula's fisheries management is based, stems largely from previously explained scientific (economic and biological) views on common property regimes. This in itself is an outcome of an "atomistic" view, that society is actually no more than the sum of individual interactions (Kapasa, Malasha and Wilson 2005). This rationalist model - forming the base of game theory - considers individuals as rational, independent and equal economic agents. In doing so, it neglects the existence and importance of power relations, politics and ideology, that affect access to, control over and (re)distribution of resources (Béné 2003; Gordon 2006, 2005; Haller and Merten 2008; Jul-Larsen 2003). As Annear (2010:23) argues, "no two users are purely equal in their access to knowledge, power, information and technology." Sen's (1981) "entitlement approach" - that stresses the importance of networks, social relationships and capital in receiving access to key assets and resources - supports this view. The consequences of this are twofold: poverty can exist even when enough resources are available, and inequality is an inherent feature of every human society. This questions the straightforward and linear association between poverty and resource availability and offers an essential principle behind this article: wealth characterizes small-scale fisheries as much as poverty does (Bavinck 2011).

Poverty or wealth are never static, but constantly (re)created and mediated through socioeconomic networks and relationships. This notion especially concerns fishing activities that - due to the uncertainty and unpredictability of resource extraction - contain elements of opportunity and vulnerability (Béné 2009; Platteau, 1989). Those two elements - possibilities for economic improvement and hazards of impoverishment - exist in a symbiotic relationship. This duality defines the life of any individual who is engaged in fishing activities. Platteau (1989) argues that socioeconomic relations in fisheries are often a direct outcome of this uncertainty, since investment in such relations can ensure access to certain assets and function as an insurance mechanism. As will be pointed out, socioeconomic networks have always been an important feature of both the colonial and postcolonial fishing economy in Mweru-Luapula (Gordon 2005). Yet, these connections are also constraining as they create dependencies. The assumption of independent rationality characteristic of an atomistic perspective on society - ignores these social constraints that define decisionmaking processes (Ensminger 1992, cited in Haller 2007). In this regard Haller (2007) talks of "bounded rationality", whereby formal and informal institutions - created through networks of social interactions define human action and interaction.

This gap between a fisheries policy approach that considers individuals as equal, independent and rational actors and a social reality that contradicts this is very challenging to management goals. An institutional regime, that (for instance) fails to acknowledge certain dependencies that force people to use illegal fishing methods, will hardly succeed in ensuring sustainable environmental and socioeconomic development. Furthermore it is important to realize that such networks of dependencies are not necessarily limited to a certain locality: one has to question the common notion that "local problems call for local solutions" (Annear 2010: 30). This vision is connected to the idea of a local and homogenous community, which acts as a premise for co-management initiatives. In the words of Agrawal (2005: 130), this vision implies that "communities and similar small social formations can create and sustain institutionalized patterns of interaction to govern collectively owned resources successfully, even in the absence of adverse pressures of states, demographic changes, and market forces."

Agrawal (2005) explains that, although politics can acknowledge the impact of exogenous factors - e.g. market demand - on local fisheries, the assumption persists that actions at a local scale are more likely to have desired effects than arrangements at other scales. Brown and Purcell (2005) call this the "scalar trap". Yet scale is in principle a relational concept. This means that interscalar interactions occur at the local level too. Specific interpersonal interactions and transactions are the segments through which vague and abstract concepts such as market integration and commercialization of fisheries come into being.

Human migration is one such interscalar process. From a historical and contemporary perspective migration patterns in Mweru-Luapula have constituted strong rural-urban linkages in the fishing economy. Such connections have determined the socioeconomic structure of Mweru-Luapula's fishery to a great extent - e.g. by modifying traditional production relations - to a point that one can hardly understand the local villages as "small-scale societies with homogenous interests" (Haller and Merten 2008, p. 712). 
The importance of interscalar interaction in Mweru-Luapula's fisheries supports the use of a fish chain analysis as the analytical framework (complementary to a political ecology approach). The fish chain analysis, conceptualized by Kooiman et al. (2005), focuses on the entire production chain, harvest and postharvest system. It postulates that natural and social fisheries systems are interconnected within the fish chain. Challenges, concerns and opportunities for fisheries are therefore to be found throughout the whole production chain (Chuenpagdee and Jentoft 2011). Because of this, our field research focused heavily on analyzing the interactions and transactions between fishermen, fishmongers, middlemen and fish traders.

Fish chain analysis is in fact similar to what Goldman and Turner (2011) call the intersection-processes approach, which is a characteristic of political ecology and means that "agency is distributed across different kinds of agents and scale, not something centered in one class or one place" (p. 94). Fish chain analysis is useful within a political ecology approach, which has three main commitments: 1) a commitment to understanding biophysical processes and the ecological system and not using them solely as a background context for social conflict; 2) a dedication to connecting local processes to broader social and ecological changes and 3) a strong commitment to social justice by focusing on mechanisms of political and socioeconomic subordination, marginalization and disempowerment (Goldman and Turner 2011; Hauck 2011). ${ }^{2}$ Simply stated this means that three elements are central in every observation: nature, context and power. This approach is political in two ways: 1) it focuses on the political-economic processes in which environmental change is embedded and 2) it is political in the sense that researchers are eager to change the situation they study, for example by improving standards of living or by reversing environmental degradation. This understanding should equally be present in the analysis of the political ecology in Mweru-Luapula. This means that one has to take into account the sociopolitical processes and ecological context that led to the production, application and circulation of Mweru-Luapula's knowledge base, as well as the knowledge of managers. Furthermore the application of the fisheries management regime should be studied by focusing on enforcement and compliance by taking into account the (possibly unequal) distribution of costs and benefits, its sociopolitical effects and its ecological consequences.

\section{This research}

This research on governance and the political ecology of Mweru-Luapula's fisheries is mainly composed of qualitative fieldwork data - collected through individual and key informant interviews and observations. Other data is from governmental reports and legislative documents and documents published by NGOs. The fieldwork was carried out in villages, fishing communities and administrative centers in Nchelenge District in Luapula Province from September 2011 to November 2011. Thirty-five key informants were interviewed from various backgrounds, including:. fishermen, chisense fishermen, female fish mongers, urban fish traders, VMC (Village Management Committee) members, community headmen, traditional authorities, government and NGO officials, Director of Fisheries, etc. The interviews were semi-structured, in-depth and open-ended. Observations were made at the Nchelenge fish market and through patrolling on Lake Mweru with the Immigration Office and representatives of the Village Management Committee and the Department of Fisheries.

\section{Mweru-Luapula's biophysics: a story of resilience}

The Mweru-Luapula fishery includes Lake Mweru, its islands, the Luapula River with its lagoons and swamps and flood plains from Mambilima Falls south to Mwense up to Lupiya at the Lunchinda River. The border between the Democratic Republic of Congo (DRC) and Zambia runs right through the lake, the river and lagoons (Figures 1 and 2). As we will see later, the nature of Lake Mweru as a cross-border resource has been a determining factor for both management and the political ecology of Mweru-Luapula.

Lake Mweru is an allotrophic lake, due to the inflow of the Luapula River into the lake and the outflow of the Luvua River to the north. This means that total fish production is highly dependent on the constant in- and outflow of nutrients (Mölsä 2009; Van Zwieten, Goudswaard and Kapasa 2003). This also means that a lot of fish species have high but also highly variable yield potentials. An important consequence of this is that the lake's ecology offers a biological counter to the "Tragedy of the Commons paradigm". This is because allotrophic lakes are known to have low susceptibility to increased fishing efforts and a high but variable recovery rate (Van Zwieten, Goudswaard and Kapasa 2003). Mweru-Luapula therefore has two main biological characteristics that are essential to this article: it has a high variability of fish species and ecological resilience that is rare among common-pool resources (Annear 2010).

\footnotetext{
${ }^{2}$ As Walker (2005) explains, a debate currently takes place between those who argue political ecology should mainly focus on the biophysical and those who concentrate on the social and political aspects of ecological change. Without taking a methodological stand too firmly, this article tries to look at how all aspects - social, biological, ecological, institutional, economic - are intertwined and how they mutually influence each other.
} 


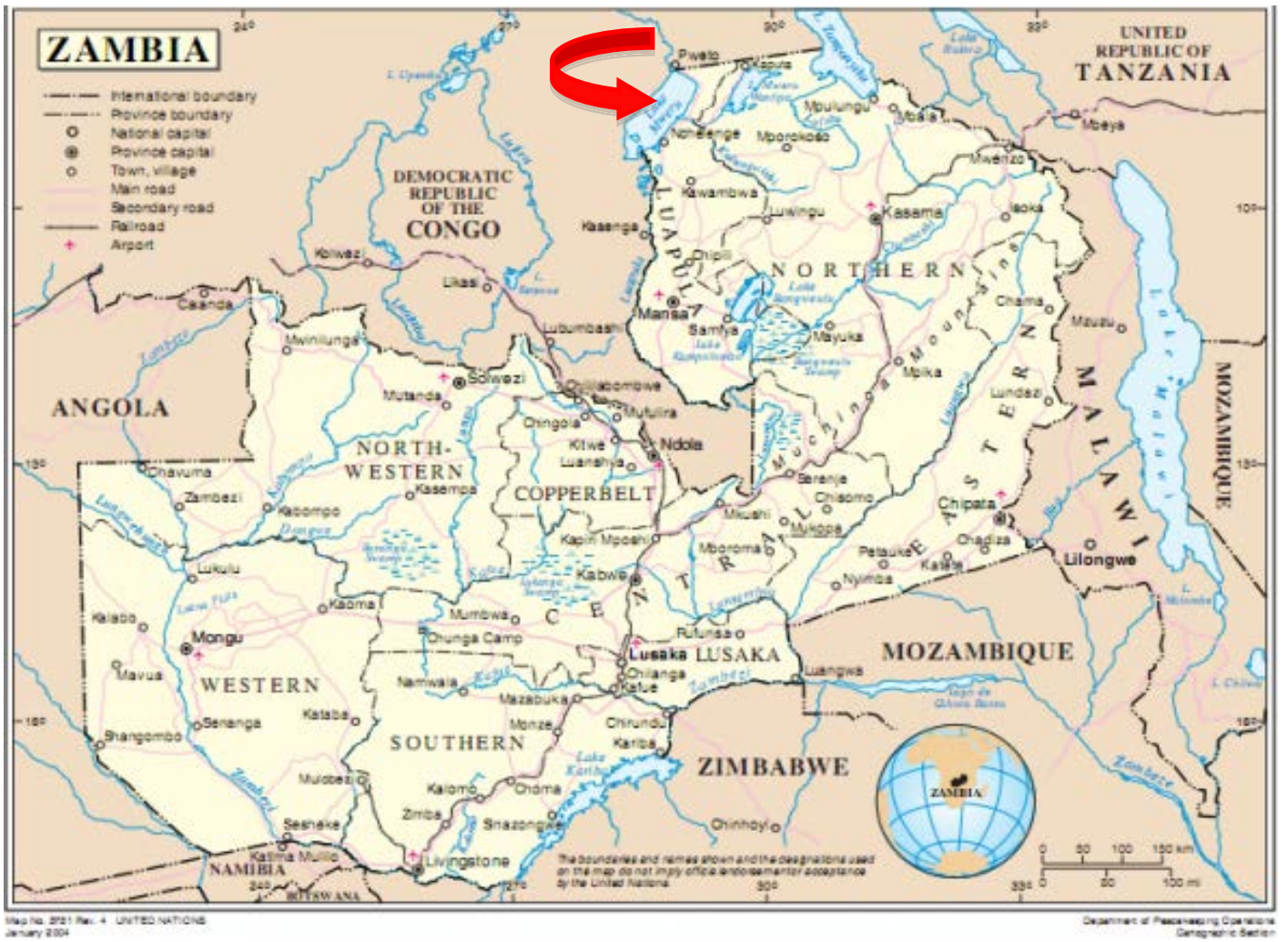

Figure 1: Map of Zambia with Lake Mweru highlighted. Source: United Nations, January 2004.

Those two features are intertwined, as ecological resilience in this case means that certain species can sustain extensive fishing pressure but also that a reduction of fish levels of a certain species often goes together with the rise of another. It is easy to observe the Lake's potential to avert environmental degradation, yet this depends on the adaptability and resilience of fishermen, fish traders and the market to these biological variations to evade impoverishment too.

Numerous works on Mweru-Luapula's fisheries describe its system as an economy built by a dynamic population of fishermen using an ecological resilient resource (Annear 2010; Gordon 2006; 2005; Jul-Larsen and Van Zwieten 2002; Van Zwieten, Goudswaard and Kapasa 2003). Even the current management regime takes the view that - in principle - an ecological equilibrium could define Mweru-Luapula's fishing resource. From this perspective change is brought on by external factors such as population pressure - e.g. caused by permanent and seasonal migration - that can be problematic as they disturb this balance and could eventually cause biological depletion. Yet we argue that change is the interaction between the endogenous (e.g. institutions, ideology, organization) and exogenous (e.g. social and physical environment, population and technology) aspects of a society (Ensminger cited in Haller 2007).

The following sections on the historical evolution of Mweru-Luapula's fishing economy therefore focus on the social constraints and incentives for individuals, within the broader context of socioeconomic and political change.

\section{Meanings of wealth and poverty: historical trajectories of governance and political ecology}

To show that wealth characterizes inland fisheries as much as poverty does, this article disputes two common assumptions that greatly influence the management regime of Mweru-Luapula. The approach of fisheries as an activity of last resort for impoverished households lays claim on clarifying the cause of migration into and outside of fisheries as a livelihood (Cinner, Daw and McClanahan 2008; Van Zwieten, Goudswaard and Kapasa 2003). The second presumption concerns the linear and often simplified link between migration and the biophysical nature of a common-pool resource. Without denying environmental effects of population pressure, the next sections argue for a more holistic approach that starts from the wider context of migration and incorporates socioeconomic and institutional consequences too. 


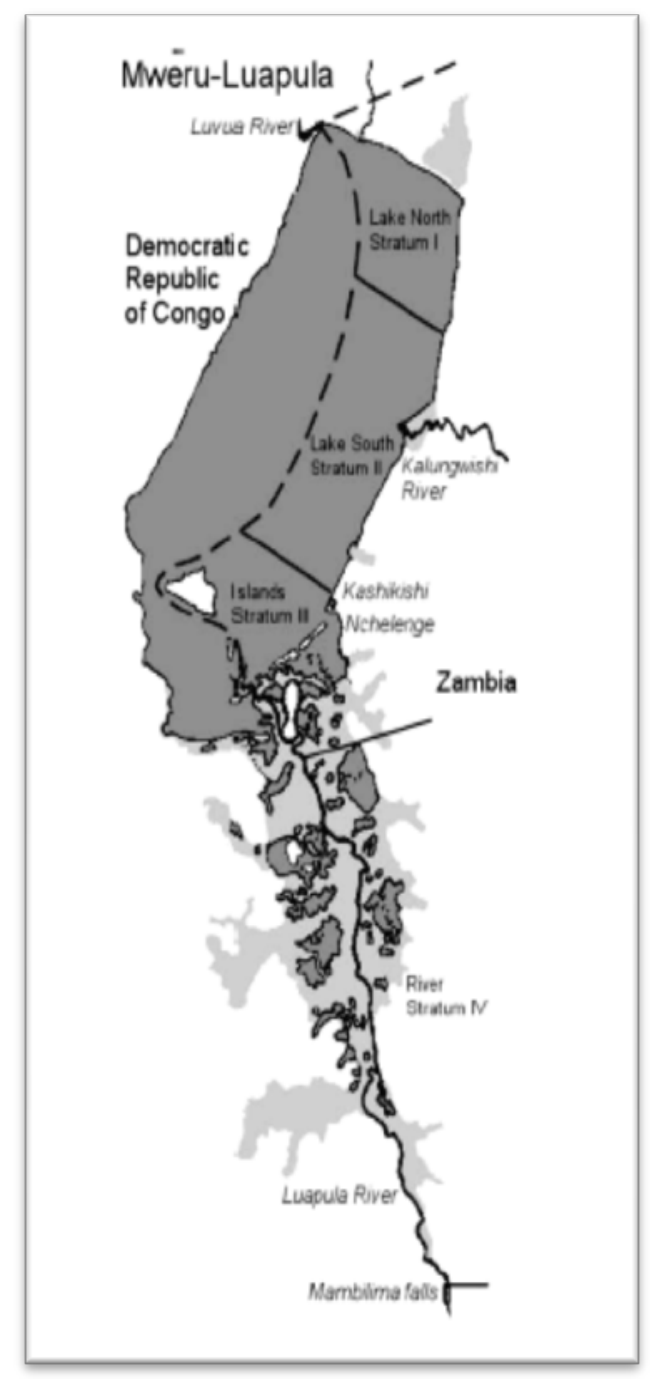

Figure 2: Map of Mweru-Luapula Fishery System. Source: Zambia Department of Fisheries.

\section{Colonial capitalism}

The Mweru-Luapula region has historically been characterized by strong seasonal and permanent migratory patterns (Mölsä 2009). This observation is connected with the role of the Luapula valley as a center for regional trade at least since the eighteenth century and with its history of conquests (Gordon 2003). Various oral traditions narrate the legends of settlers and conquerors, among which the conquest of the Luapula valley by the eastern Lunda tribes under Mwata Kazembe - and the following establishment of the Kazembe Empire - is probably the most imaginative and well known. Yet the most crucial and decisive story of conquest is provided by Zambian and Congolese colonial history. In respect to Mweru-Luapula's fisheries, some important migratory movements took place under colonial domination.

During British and Belgian colonial rule, European - mostly Greek - fishermen and fish traders were encouraged to start their economic activities on and around Lake Mweru (Gordon 2005). The context of their presence - situated historically at the beginning of the twentieth century and especially the 1920s and 1930s has to be understood through the efforts to industrialize and commercialize the fishing economy in MweruLuapula (Musambachime, 1995). Urban markets in the Zambian Copperbelt but especially in Elisabethville near the booming copper mines controlled by Union Minière du Haut Katanga (UMHK) - demanded a stable supply of fish (Annear 2010; Gordon 2005; Malasha 2003). This encouraged expatriate merchants and fishermen who owned sufficient capital to start commercial activities in Mweru-Luapula (Jul-Larsen and Van Zwieten 2002). Both the Belgian and Northern Rhodesian colonial administrations shared the idea that such a form of capitalized entrepreneurship was desirable. The Northern Rhodesian administration however 
preferred indirect rule policies to reach this objective, while the Belgians seldom placed resources under the control of local tribal and traditional authorities (Nugent 2004).

The coexistence of two different views on colonial management - a paternalistic and authoritarian system versus an approach whereby native authorities were given decision-making powers to some extent was an important feature within Mweru-Luapula's economic and political system. For one it meant that fewer expatriate fishermen and traders were present on the Northern Rhodesian side of the Luapula. This was important as it slowed down the process towards a commercialized fishery in Northern Rhodesia. Furthermore, enforcement of unpopular legislation concerning resource management - like the implementation of a closed fishing season in the Luapula River to protect the mpumbu's spawning run - had worse effects in Northern Rhodesia, since the responsible native authorities were accountable to the people whose livelihoods depended on the juvenile fishing of this commercial species.

The difficult task for the local chiefs of mediating between communities and the administration, to enforce colonial legislation on the one hand and maintain authority and respect with local fishermen on the other, exposes a vital feature of the indirect rule system. At the same time it uncovers an ambiguous relationship between enforcement of fisheries legislation and local compliance. Within the Northern Rhodesian administration, this duality was expressed by the linking together of unpopular conservation measures and development projects (Gordon 2005). Regarding fisheries commercialization, such development projects actually stimulated the formation of African capitalized entrepreneurs above simply ensuring compliance. For instance, the construction of an ice plant in 1955-56 and the improvement of road infrastructure made the fresh fish trade a less expensive undertaking and therefore encouraged participation of African traders. ${ }^{3}$ This means that the fisheries commercialization did not just discriminate against local communities by pushing households out of fishing activities. Due to the indirect rule system of governance, artisanal and small-scale fishing continued to coexist alongside more commercial fishing, and even converged in part as a number of small-scale African fishermen were able to transform themselves into more capitalist entrepreneurs towards the end of the 1950s.

The nature of the colonial administration in Northern Rhodesia, together with the opportunities for social mobilization - an integral feature of capitalism - created decentralized political and economic networks wherein a local elite was able to form. It is important to note that this was not only a formal process instigated by the granting of authority to colonial chiefs. A new civil society emerged, guided by commerce and capital. Aimed at monetary accumulation, new economic alliances based on credit and trust came into being. Such networks often began with the expatriate traders who extended goods to African traders, who in turn exchanged them for cash or used them as credit for fishermen in exchange for a predetermined amount of fish (Gordon 2006). Economic growth in the Copperbelt and nearby cities also stimulated distribution of new goods and materials to rural areas like the Luapula valley. This promoted the swift rise of small businesses in fishing villages such as Kashikishi and Pweto. From this moment on, Mweru-Luapula's economy would be largely driven by capitalist standards and commerce that - according to David Gordon (2006:103) - "swept away established hierarchies of political power, kinship patterns, and forms of social organization." In fact the relationship between traditional and capitalist forms of organization remains ambiguous. For one thing both patterns coexisted, as commercial fishing occurred for the most part on open waters, while subsistence fishing remained in the swamps, lagoons and shallow waters where more traditional tenure rules are employed. Secondly, traditional production relations based on kinship were not just replaced by large-scale organizational forms, as they often continue to exist even when incorporated in a larger economic and commercial system (Platteau, 1989).

Yet one cannot neglect the reality that the rise of a new capitalist entrepreneurial class will inevitably collide with a traditional elite based on custom and heritage. As elite formation is an essential feature of capitalist development, it necessarily includes mechanisms of exclusion and marginalization. In MweruLuapula's colonial fisheries this was visible from both a political and ecological perspective. Incidences of local opposition and rebellion against the colonial administration gradually increased, as colonial administration policy and legislation mainly served to protect the rights of wealthy expatriates. This had notable ecological effects as the expanding commercial efforts eventually led to the disappearance of the mpumbu fish, which had become a highly commercial commodity. Yet the mpumbu fish was also targeted for subsistence purposes through customary practices in traditional fishing communities. Its gradual depletion increased competition - between subsistence fishers and with the recently installed European-driven commercial fishing economy - and forced many households to migrate out of Mweru-Luapula. This pattern of out-migration was further driven by growing industrialization and urbanization in Northern Rhodesia and the Belgian Congo, which incited rural-urban patterns of labor migration, meaning households became attracted by more profitable employment opportunities in other economic sectors (Annear 2010; Ferguson 1999; Gordon 2005).

\footnotetext{
${ }^{3}$ Gordon (2006): From 1955 to 1956, the share of fresh fish traded by Africans increased from thirty five per cent to approximately seventy per cent of total fish trade.
} 


\section{Independent nations: state patronage and rural development from a government perspective}

During the 1960s and 1970s a decline was witnessed in catches in Mweru-Luapula's fisheries, corresponding with a decrease in capital investment. Reasons for this can be found in the local and regional context. Without mpumbu the fishery was less profitable. Its disappearance eventually made European expatriate fish traders and fishers leave the Luapula valley. Catches of pale and other commercial species had also diminished. While from a government perspective this was presumably caused by harmful fishing techniques, the reality of a succession of droughts affecting breeding and spawning possibilities, seems regarding Lake Mweru's allotrophic nature - a more plausible explanation for the decrease in fish levels (Gordon 2005).

Yet regional economic outcomes also affected fisheries investment. From the beginning of the 1970s, many mining companies in the Katangan Copperbelt ceased to provide their workers with food rations - a form of payment - and consequently stopped signing contracts with capitalist fish traders. Almost simultaneously, copper prices collapsed. This influenced the process of industrialization in Zambia and Zaire, which began to slow down after a long period of rapid expansion. This had immediate effects on MweruLuapula's commercial fishery, as it had become highly dependent on urban and industrial demand.

Furthermore the postcolonial institutional and political context affected the fishery. The Zaireanization decree of 1973 resulted in the confiscation of expatriate industries by President Mobutu Sese Seko. In their place, the President installed allies who often lacked the necessary knowledge of fish production, processing and marketing, to run fishing companies in Zaire. In Zambia, development plans in the 1960s and 1970s were drawn up to actively support rural production through the formation of cooperatives, the provision of credit and the centralization of product marketing. In Mweru-Luapula, this resulted in the take-over of the Kashikishi ice plant by a parastatal organization called Lake Fisheries of Zambia (LFZ). This organization became the central marketing board. At the same time fixed market sites were established at the lakeshore, and regulated pricing sought to counteract proliferation of fish prices. The objective was preventing fishermen from being exploited by fish traders, and eventually even eliminating the need for those private traders. The provision of credit by the rural development program to fishing cooperatives should be analyzed as an attempt to unite fishermen in one or more controllable and monitorable organizations.

The story of Gabriel Kunda, a fisherman in Kashikishi, exemplifies the opportunities and weaknesses of these development programs (Mr. Kunda, personal communication, October 6, 2011). In the early 1960s, he moved from Mansa - Luapula Province's provincial capital - to become a fisherman like his parents had been. Using government credit, he was able to buy two marine engines and seventy nets. He did not process his fish but sold it directly to Isabi Investment, the Kashikishi ice plant owned by LFZ. In 1964 he founded a fishing cooperative through which fishermen could look after and protect fishing nets and boats. He had forty-two fishermen who worked on his behalf and shared in his profits. The government's pricing policy, however, provided these fishermen with the incentive to sell portions of fish while out on the Lake to private traders, instead of selling them at the fixed marketing points to Isabi Investments. To prevent fish being sold to traders on the lake without him knowing, Mr. Kunda utilized credit ties with his fishermen by giving them cash or fishing gear in advance. Yet networks of kin and credit also existed between his fishermen and private traders. Although Mr. Kunda made good profit in the first years, his business eventually slumped because of the decline in pale catches and the low prices the buying depot in Kashikishi offered. Mr. Kunda's story is not uncommon. The development programs and the LFZ collapsed in 1979. This was bound to happen since socioeconomic relations - based on mutual gain and dependency - between private traders and fishermen persisted and even became stronger as the real income of fishers was being decreased by the government's pricing policy. The system of state patronage was unable to compete with existing networks between fishermen and fish traders.

Gordon (2005:104) argues that "by the late 1970s, only remnants of the colonial fishery were left." This applies to the institutional context too. Although in 1974 the Department of Fisheries (DoF) was created and the Fisheries Act decreed - an ordinance that provided for the development and control of fishing and the registration of fishers and boats. This centralized process did not succeed in replacing former colonial and traditional regulation systems with formal state policy (Malasha 2007). For example, fishing restrictions in the Mifimbo breeding area were abolished after independence, and efforts to install a closed fishing season could not be enforced until 1986 (Annear 2010; Gordon 2005). Eventually, state absence and incapacity in the Luapula Valley granted almost unhindered access for any individual with the means - i.e. capital and knowledge - to exploit the fishing resource.

\section{Private victory: the emergence of the patrons}

From the 1970s onwards, the fishing population in the Luapula valley grew dramatically. As Van Zwieten, Goudswaard and Kapasa (2003) showed - based on their 1997 frame survey - one fifth of all fishermen were born outside the Luapula area. This shows that population growth largely resulted from migratory movement, which was inherently linked to the regional and urban context in the Copperbelt. The crisis in the mining industry in the 1970s and the subsequent contraction of the formal sector caused by the externally laid on reforms of the Structural Adjustment Programs by the end of the 1980s and 1990s, pushed numerous people into small-scale fishing which thus served as an informal safety net (Gordon 2005; JulLarsen and Van Zwieten 2002; Kapasa, Malasha and Wilson 2005; Malasha 2007). A lack of employment 
opportunities made many households move back into the rural economy (Ferguson, 1999; Islam 2011; Nugent 2004).

Yet it would be over-simplifying to analyze population growth in Mweru-Luapula solely through seeing fishing as a last resort. Although commercial fishing activities decreased, they did not disappear. The departure of European fishermen and traders created a vacuum that in fact offered further opportunities for both Zambian and Zairian entrepreneurship. Moreover, retrocession of the Zaireanization process towards the end of the 1970s led to the return of some business ventures to their original owners (Nugent 2004). The story of Zairian businessman Katebe Katoto is exemplary of this. Through a lucrative contract with Gécamine - in former times called UMHK - he continued to supply fish to the copper mines in Katanga. He dominated the entire Zairian side of the fishery and even offered Lake Mweru to Mobutu Sese Seko for purchase (Gordon 2006, 2005). Although Katebe Katoto was probably the biggest patron Lake Mweru has ever seen, he was certainly not the only one. Many Zairian and Zambian fish traders used labor and credit ties to elaborate an extensive economic network based on patron-client relationships. More often than not these patrons - who saw economic opportunities in the fish trade - came from elsewhere. This is understandable for the following reasons: 1) many of them 'returned' to Mweru-Luapula and/or already had relatives or acquaintances engaged in fishing activities; 2) they had been able to generate capital through other economic activities, making it possible to invest directly in fishing gears and labor; and 3) their urban social networks gave them a comparative advantage over other "autochthonous" fish traders with respect to fish commerce.

An economic system based on patronage was primarily stimulated by the nature of pale fishing, which became the single most important commercial species after the disappearance of the mpumbu fish. Pale - also called green-headed bream - mostly live in the open waters of the lake, while floodplains and beaches are used for breeding (Gordon 2006). The catching of pale therefore demanded more capital-intensive equipment including expensive nylon nets and fishing boats. Consequently, many fishermen depended on creditrelationships with Zambian and Zairian traders for the provision of this equipment. Private traders supplied nylon nets in exchange for a predetermined quantity of fish. These economic transactions functioned as an insurance mechanism for private traders who established a base of dependent fishermen - hence a stable supply of fish. As a new road was constructed on the Zambian side of Lake Mweru, urban areas became far more accessible through Zambia than through Zaire. This advantage made many Zairian traders move their business from Pweto and Kasenga to growing Zambian fishing towns as Kashikishi and Chiengi (Musambachime, 1995).

In summary, migratory movement towards the Luapula valley did not only result from a deteriorating external economic context but was also stimulated by the economic opportunities of pale fishing. In this fishing economy, private traders became essential key players as the need for capital to engage in pale fishing could not be met by state initiatives. More traditional fishing methods in the lagoons and at the shoreline targeted juvenile pale by the use of weirs and traps. This fishery was - like the colonial mpumbu fishery more locally based than out on the open lake. Yet the targeting of juvenile fish was also directly related to capital-based pale fishing. The promise of future catches within the patron-client relationships forced fishermen to target juvenile fish when other catches proved to be insufficient. Furthermore not all fishermen were able to obtain credit to buy the necessary fishing gear. Opportunities for receiving credit were for instance much lower in more remote areas where fresh fish trade to the urban markets was not possible.

The success of open lake pale fishing naturally depends on successful breeding periods. This makes the targeting of juvenile fish a hazardous occupation. Lake fishers and patrons therefore called for stronger restrictions on fishing in breeding areas. In 1974, the Zambian authorities therefore tried to enforce strict fishing regulations in the Mifimbo breeding area - which is an important place for the spawning of pale fish. However, several factors contributed to the constant failure of these regulations. The poor monitoring capacity of the Department of Fisheries and the ambiguous role of Traditional Authorities and local politicians - especially during election times - towards fishermen in the Mifimbo breeding area made enforcement of such measures weak.

The high prevalence of credit in the patronage networks forced fishermen - due to of the hazard of debtrecycling - into illegal fishing methods. Efforts to prohibit the catching of juvenile fish to protect the commercial open-lake pale fishing falsely juxtaposed subsistence fishing against a commercial fishing economy. The distinction between traditional and commercial fishing is partly an invented one, due to the nature of juvenile pale fishing as an undercapitalized commercial activity (Annear 2010). Moreover, Malasha (2003:257) indicates that fishing regulations in Zambia usually - without scientific evidence - considered local fishing methods as "inherently harmful."

Yet the destructive impact of juvenile fishing in the 1970s and 1980s has been overexaggerated. As mentioned, Mweru-Luapula's waterbodies can sustain intensive fishing pressure in high fertility years. Despite growing exploitation - due to an increasing number of fishermen in open-lake pale fishing and shoreline juvenile fishing - total pale catches stayed relatively constant. Many argue that fluctuation in levels were not so much determined by exploitation effort but by weather conditions (Annear 2010; Gordon 2006 2005; Jul-Larsen and Van Zwieten 2002; Van Zwieten, Goudswaard and Kapasa 2003). As Gordon (2006:146) argues, "a good rainy season allowed for stock replenishment." 


\section{Swimming gold? The rise of chisense fishing}

Increasing exploitation levels - due to population pressures - did not seem to cause environmental degradation directly, yet total catch per capita decreased. As fishing effort became greater, competition grew. This limited profits for many. The rise of chisense fishing throughout the 1970s and early 1980s is therefore as much an example of the adaptability of Mweru-Luapula's fishing population as a consequence of its ecological resilience. Chisense are small lake sardines that live in large shoals in the upper layers of open waters. Chisense stock levels increased dramatically in the 1970s, probably due to changing nutrient levels in Lake Mweru, caused by a growing lakeshore population and the use of artificial fertilizers (Gordon 2006). What makes chisense special is its incredible resilience to high exploitation levels, caused by its extremely high turnover rate. ${ }^{4}$ Traditionally chisense was caught - for subsistence needs - in shallow waters close to the sandy shores of Pweto and Chiengi, by women using small seine nets or even clothing. The increasing numbers of chisense fish and the ease of capture gradually led women to dry the fish and sell them locally. The commercial potential of chisense was high on both sides of the fish chain. It was easy to catch and process, there were plenty, and the urban markets demanded a large supply of cheap fish. Its commercial potential attracted entrepreneurs who started using a more capital-intensive method of chisense fishing. By means of paraffin lamps to attract lake sardines by night, and small mesh or meshless material to drag the fish, the total catch per capita could be up to fifty kilograms per night (Gordon 2005). This technological innovation not only increased total production but commercialized chisense fishing to a capital-intensive occupation that required specialist knowledge and experience.

The rise of the commercial chisense fishing in the early 1980s occurred alongside customary net fishing. Since a lot of fishermen relied on patron-client credit relationships, they were tied to their usual fishing practices and lacked alternative credit to diversify their economic activities. Therefore mostly migrant fishermen engaged in chisense fishing. A new class of semi-urban entrepreneurs was formed along the shores of Lake Mweru. Contrary to the patrons in pale fishing they lacked an extensive patronage network. This was partly due to the nature of chisense as a migratory species, which made credit relations more precarious as chisense fishermen have to follow the large shoals of fish from place to place. Secondly, the high level of competence needed for chisense fishing makes such patronage networks difficult to establish. Employees on chisense fishing boats mostly work one year for a gear owner to be able to buy their own gear and to start their own business (chisense fisherman, personal communication, October 13, 2011). Relationships between gear owners and boat workers are therefore more temporary and contractual. Economic bonds between gear owners exist as well: often they use one large boat to transport the sardine catch all together and fuel costs are shared. This system of cooperative labour is not based on kinship or custom, but is economic in nature as it reduces costs for all stakeholders involved.

Unlike chisense fishing, the processing phase in the fish chain is far from capital-intensive. After chisense is dried in the sun it can simply be sold or transported to urban markets. Therefore local women, who were involved in the processing of chisense and the small-scale trade, were able to earn an income independently. Gordon (2005, 2006) and Annear (2010) correctly postulate that from a gender perspective this was an essential impulse for women's empowerment. Until now, women continue to have a very strong position in the chisense fishing economy. Chisense traders who only intervene in the marketing stage are forced to buy from these female traders - called abakukungwisha. Their success is further signalled by the fact that nowadays they provide starting chisense fishermen with money or fishing gear in exchange for fish. As we will see further, the role of women in Mweru-Luapula's fishing economy has become more significant over the last few decades.

\section{Competition and conflict: from state absence...}

The important consequences of meteorological factors for Lake Mweru's ecology are that good years can be followed by bad years and vice versa. The nature of the Mweru-Luapula fishery is therefore rather one of unpredictability - thus insecurity - than one of gradual environmental degradation.

Nonetheless, fluctuating catches did affect the nature of the pelagic fishery and had social and economic consequences too. Towards the end of the 1980s catches per unit in the gillnet fishery had decreased from 10kg/unit/night in 1980 to 4kg/unit/night in 1986 (Mölsä 2009). The general responses from the fishing communities surrounding Lake Mweru included technological change and an increase in scale. The former means that fishermen generally shifted to smaller mesh sizes while the latter comes down to the use of more nets per fisherman. Both responses did require the necessary amount of capital to change and/or purchase fishing gear. That is why cases of net theft increasingly occurred towards the end of the 1980s. Even more, the use of self-improvised fishing gear like mosquito nets or even piece of clothing grew, which became heavily criticized for their destructive effects on juvenile fish (Gordon 2005; Kapasa, Malasha and Wilson 2005; Malasha 2007; Wilson et al. 2010). This critique extended itself to illegal fishing techniques too, like beach seining - a technique whereby large amounts of small and juvenile fish and even fish eggs are dragged

\footnotetext{
${ }^{4}$ Gordon (2006): it is estimated that the ratio for chisense could be between five and six, which means that the total weight of chisense caught in one year can be up to six times greater than total weight of chisense present at any time during that year.
} 
towards the shoreline using large small-meshed fishing nets. The use of such illegal fishing gear and methods, and the fishing activities on Kanakashi and Potolo Islands - settlements based in the Mifimbo breeding area were targeted as the causes for the continuing decrease in catch per unit. Accusations of illegal fishing were often connected to an autochthonous discourse whereby recently arrived migrant fishermen were blamed for destroying Mweru-Luapula's fish populations (Wilson et al. 2010). Yet, residents from Kanakashi and Potolo Islands utilised an indigenous discourse, arguing for the protection of their "traditional" fishing practices. While the spreading of illegal fishing gears was many a time distributed through the same socioeconomic networks that had defined the pale fishing in the 1970s and 1980s in Mweru-Luapula (Annear 2010). Exemplary of this are the accusations towards Congolese traders - who had often arrived in Zambia during the heydays of the pale industry - as the main providers of illegal fishing methods and gears.

\section{...to state incompetence}

The prevalence of illegal fishing, and especially net theft, generated many conflicts in the surrounding fishing communities. This led to important trends that would define the current co-management fisheries regime. Firstly, these events in the late 1980s laid the true base for a discourse that links decreasing catches directly to illegal fishing: 1) increased competition - caused by population pressure - gives many fishermen an incentive to use illegal fishing methods to maximize their profits; 2) without restrictions to these practices, a 'Tragedy of the Commons' would be unavoidable.

This narrative was a guideline for fisheries conservation measures. In 1974 fishing regulations to deal with juvenile fishing were already introduced, but enforcement capacity was low - the DoF lacked the necessary resources, namely fuel, to patrol regularly. Throughout the 1980s, the declining catches per capita led experts and policy makers call for the reintroduction of a closed season. The last successful closed season policies dated back to the colonial restrictions to protect the mpumbu spawning run. In 1986 the Zambian authorities agreed on a closed season from December to March, following Zairian success to restrict fishing in this period..$^{5}$ The closed season policy was supported by wealthier fishermen who were able to bridge this period financially and who could even support more small-scale fishermen through their patronage network, which in this case functioned as an informal insurance mechanism. Yet, independent small-scale fishermen who saw their income cut off for three months - resented the closed season, just like the fish traders did. The issue of compliance was inherently linked with low enforcement capacity of the DoF and state officials who often - in turn for bribes from wealthier traders - turned a blind eye to fishing in the closed season (Gordon 2006). These practices, whereby some could circumvent regulations using financial pressure while others saw their gear confiscated by state officials, made many fishermen feel that the administrative measures were enforced unfairly. Many argued that regulations were only used by state agents to collect personal revenue, by accepting bribes and by keeping income from policing for themselves. The Local Government Act from 1991, which encouraged rural councils to collect their own finances, surely enhanced these practices (Gordon 2006).

Soon policing collapsed due to a consensus within Mweru-Luapula's fishing communities that they should not comply with the conservation measures that benefited state agents more than the fishermen. Due to this collapse, net theft increased further. This called for a new form of local organization whereby control of fishing gear could be monitored. This led to the formation of Fishing Associations (FA) aimed at controlling fishing gear theft (Kapasa, Malasha and Wilson 2005; Malasha 2007; FA Chairman Kashikishi, personal communication, October 6, 2011). The first FA was founded in Chiengi District, close to the Zairian border where net theft was rampant. Eventually this Chipungu Fishing Association moved to Kashikishi in 1988. This form of local organization would later be used as an example for a more participary approach towards fisheries management. Yet this was certainly not the only example of local institutional power in MweruLuapula. The role of Traditional Authorities and village headmen for instance has always been important in conflict resolution and local governance. Cases of net theft were often addressed by these local authorities who had the power to punish or even evict someone from their communities (village headman Nchelenge, personal communication, September 30, 2011).

\section{The interpretation of history}

These events in the 1980s and early 1990s helped form the body of environmental knowledge that constitutes the actual policy perspectives applied in Mweru-Luapula's fishery. To recap, this perspective starts from Lake Mweru as a common-pool resource that - after decolonization - ensured open access to anyone who wished to enter. This led to a migration movement of individuals seeking their luck in small-scale and artisanal fisheries. Population pressure consequently caused an increase in the use of illegal fishing methods and called for a policy aimed at environmental protection through law enforcement,monitoring, control and surveillance practices to counter illegal and unreported fishing.

By discussing the political ecology of Mweru-Luapula's fisheries from the colonial period onwards to the early 1990s we have questioned the premises on which this management regime is based. Firstly, the

\footnotetext{
${ }^{5}$ Gordon (2006): this success was actually largely caused by good rains during the closed season, which made pale stock levels grow steadily during the Zairian closed season.
} 
nature of pale and chisense fishing - the two most important commercial species after colonial dominationas capital-intensive economic activities, does not support the idea of the open-access nature of Mweru's fishery. Access to knowledge and capital is essential. These assets are distributed through socioeconomic networks that define the pale and chisense fishing economy - albeit in two different ways. Wealth and knowledge are distributed through these networks, yet in an unequal way. The assumption that MweruLuapula's fishing economy consists of equal, rational and independent economic agents goes beyond the existence of socioeconomic relations that generate and sustain inequality and create networks of dependencies. The notion of inequality and interdependency challenge this dominant rationalist model based on an economic concept of community - characterized by perfect transactions of costs and information.

The next sections will explore such economic networks in the current fishing economy in depth to uncover such social constraints and incentives, which influence people's actions. Regarding the comanagement regime - that focuses heavily on illegal, unreported and uncontrolled fishing - this implicates among other things, that policy has to make a distinction between those "who are maximising gains from illegal fishing and those who are simply relying on resources for their livelihood" (Hauck 2011: 208).

\section{Parallel transformations: institutional and socioeconomic change}

\section{Towards decentralized resource management}

The inability of central government policy to enforce conservation regulations, together with the persistence of conflicts with regard to net theft, led to the establishment of the Conservation and Management Action Plan (CAMAP) by the DoF in 1992. This was a program aimed at elaborating a participatory approach to fisheries and conservation management (Kapasa, Malasha and Wilson 2005). In 1994 advice was sought from the FAO to revise the 1974 Fisheries Act. ${ }^{6}$ This consultation led to recommendations to decentralize fisheries management obligations to local fishing communities (Malasha 2007). During 1996 and 1997 a consultative process - with the help of Dutch aid organisation Stichting Nederlandse Vrijwilligers (SNV) was executed through the Fishing Associations. This was to create a new co-management structure around Lake Mweru, which was established at three levels (Kapasa, Malasha and Wilson 2005; Malasha 2007). At the local level seventy-eight Village Management Committees (VMCs) were founded, which include grassroots stakeholders including fishers, farmers, businessmen and fish traders, and village headmen. Zonal Management Committees (ZMCs) were raised at chiefdom level: consisting of the chief or sub-chief, a fisheries officer, FA members, a council representative and other interest groups such as more large-scale fish traders. Ultimately the Mweru-Luapula Fisheries Management Committee (FMC) came into being, comprising the senior chiefs in the area and a DoF representative (Mölsä 2009). Despite these restructuring efforts, decision-making power still remained above the created institutions, as the 1974 Fisheries Act had no legal provision on the participation of local stakeholders in the management of fisheries (Fisheries Act, 1974; Musumali et al. 2009). As a result of this, the VMCs lacked formal authority. Furthermore the heavy involvement of the Traditional Authorities (TA) in the co-management structure was notable. Their role is not uncontested: on the one hand it is shown that involvement of TAs is necessary for co-management initiatives to succeed, on the other hand they also have their own private interests that can thwart decision-making capacities from the fishermen themselves and counteract the interests of co-management programs (Kapasa, Malasha and Wilson 2005; Malasha 2007; Wilson et al. 2010).

In 2007 the Fisheries Amendment Act was proclaimed, which officially provided for the creation of Fisheries Management Areas that would be responsible for the development of Fisheries Management Plans. The Fisheries Amendment Act set the stage for the creation of the new 2011 Fisheries Act and for the management of Mweru-Luapula's fisheries (Mölsä 2009). This new Act legally provides the opportunity for the creation of VMCs, ZMCs and a covering FMC - which consists of delegates of the local fishing communities, TAs and local authorities, delegates of non-governmental organizations, commercial fishing operators and the aquaculture industry (Fisheries Act 2011).

In Mweru-Luapula, new co-management structures were created in 2007 and 2008 through the support of the Programme for Luapula Agricultural and Rural Development (PLARD), which is a programme jointly funded by the Governments of Zambia and Finland. The implementation of this project - for which the 2007 Fisheries Amendment Act supported the set-up - led to the creation of 77 VMCs and 14 ZMCs. In 2010 a Fisheries Management Committee was put in place.

\section{Evaluating compliance against enforcement}

The main goal of the Mweru-Luapula Fisheries Management Plan (FMP) is to promote sustainable development by ensuring ecological sustainability, which means maintaining the base stock and species at acceptable levels (Mölsä 2009). Ensuring sustainability of fish stocks is strived for by limiting and controlling

${ }^{6}$ Director of DoF, personal communication, September 22, 2011: the 1974 Fisheries Act was practically a copy of the Game Ordinance Act, which implied that fish were seen only as food and not as a source of income or a livelihood activity. 
overall fishing effort - principally by opposing illegal, unreported and uncontrolled (IUU) fishing. The monitoring of overall fishing effort stems from the idea that too many fishermen and fishing nets are putting high pressure on the lake's ecology. As Hanna Mölsä (2009) - a PLARD officer - indicates, the nature of fishing has become more investment driven. This is supported by the fact that the number of nets per boat has increased from 30 to 50 nets per unit in the 1990s up to 200 to 400 nets per unit today. ${ }^{7}$ Simultaneously the number of fishermen on the Zambian side of Lake Mweru has increased fourfold since the 1970s.

To control the number of fishers, boat and gear, a system of fish licensing was reintroduced, whereby fishermen have to pay license fees according to the gear they use. Formally, this is the main system restricting access to newly arrived fishermen. ${ }^{8}$ At village level, however, a customary mechanism exists as well, whereby newcomers have to bring a reference letter from their former village headman underwriting their character (Annear 2010; Village headman Nchelenge, personal communication, September 30, 2011).

The licensing system also serves as a source of revenue for the VMCs, who legally have the obligation to collect license fees on behalf of the DoF ${ }^{9}$ However, weak patrolling and enforcement capacity still allows unlicensed fishing with impunity - largely due to a lack of funds (Fish businessman, personal communication, October 7, 2011; DoF Officer, personal communication, September 30, 2011). This applies to the controlling of a maximum number of gillnets per unit as well. ${ }^{10}$ Another controlling mechanism is foreseen in MweruLuapula's FMP, namely use of fish levies, which are taxes on transported fish. According to the Local Government Act (2004, Art. 69/1/b) this is a responsibility of the council. However they do not have the capacity to collect these levies in the fishing camps and on the islands, where most of the fish is transported to the urban markets (DoF Officer, personal communication, September 30, 2011). Finally, efforts are being put in place for the promotion of alternative sources of income, generated through cassava cultivation for example, but also through the development of aquaculture - i.e. fish farming - to reduce pressure on the lake's resources (Mölsä 2009). Gordon (2006) and Annear (2010) have explained that many households combined farming and fishing activities in the past. Although these livelihood diversification measures have potential to improve the local economy, living standards and nutritional health - and therefore can promote sustainable development - they do not target all households in Mweru-Luapula. After all, the most vulnerable households - living in the fishing camps - are full-time fishermen without any formal ownership of property and therefore without any land to cultivate for farming or aquaculture. ${ }^{11}$

Mweru-Luapula's FMP also comprises monitoring, control and surveillance (MCS) of IUU fishing. This illegal fishing includes activities during the annual fish ban - from December to March - and in the restricted breeding areas, and of course the use of illegal fishing gear and methods. An essential component of this policy involves public awareness campaigns in the villages, in fishing camps and on the islands. Such campaigns are proving to be successful, in the sense that illegal fishing methods and fishing when and where it is prohibited are almost unanimously identified as the main issues to be tackled in Mweru-Luapula's fisheries. This local consensus does not necessarily justify the strong focus of the FMP on IUU fishing. In this regard Agrawal (2005) points to the concept of "environmentality" whereby decentralisation of regulation by creating governmentalized localities - in this case the formation of local management committees - can create environmental subjects who are self-regulating and who come to think and act in new ways in relation to the environment; ways that are integrated with the interests of the State. Secondly, as fishing yields vary during high and low fertility years and seasons - linked to periods of droughts and rains - one can argue that local compliance with the focus on IUU fishing is higher in the dry season than during the rainy months after the annual fish ban.

Nonetheless such a consensus is of essential importance for the FMP to ensure compliance and cooperation with the monitoring and surveillance of illegal fishing. For instance, the high cost of lake patrolling - due to the cost of fuel - makes the inclusion of multiple stakeholders to share patrolling costs attractive. This is why the Council, VMCs, FAs, DoF, the police and the Immigration Office support current patrols. Yet, this is still not sufficient to cover the costs of regular patrolling activities. This is mainly due to the currently malfunctioning system of license fee and fish levy collection and to the historically high cost of fuel. Enforcement capacity to restrict illegal fishing therefore stays low, as regular patrolling is only possible during the annual fish ban. Furthermore the removal of the illegal settlements on Kanakashi and Potolo

\footnotetext{
${ }^{7}$ Gordon (2006): this evolution was supported by the introduction of cheap Korean fishing nets.

${ }^{8}$ As will be explained later, the Immigration Office also plays a key role in restricting access for illegal immigrants. This is very relevant for Lake Mweru as a cross-border resource, whereby Congolese fishermen often come to fish in Zambian waters. This issue is included in the FMP as well.

${ }^{9}$ Mölsä (2009): according to the FMP, fifty per cent of the licensing revenue has to be allocated to the FMC, which divides the money between the different sub-committees. However, this allocation system is still not in place as the money stays with the DoF. This causes a lot of irritation within the different committees (Fisheries Management Advisor, personal communication, September 26, 2011; Chairman VMC Kashikishi, personal communication, October 6, 2011).

${ }^{10}$ Mölsä (2009): the FMP limits the number of nets per unit to eighty nets of fifty meters length.

${ }^{11}$ DoF Officer, personal communication, September 30, 2011: in 1989 a Land Resettlement Scheme was however proclaimed, which makes it possible for anyone to acquire land from the government. Yet a lot of people are not aware of this or prefer to stay in the fishing camps as land allocation would force them to move out.
} 
Islands requires the cooperation of the resettlement scheme office in Mansa. This has political consequences as politicians usually do not dare to take the unpopular measure of forced resettlement, out of fear of losing votes (DoF Officer, personal communication, September 30, 2011; Fisheries Management Advisor, personal communication, September 26, 2011). The TAs, who are heavily represented in the co-management structure to enforce measures but have to render account to their community as well, also fulfill an ambiguous role in this (Wilson et al. 2010). ${ }^{12}$ The inability to stop illegal fishing in Mifimbo is potentially threatening for overall compliance with the FMP's conservation measures. As a DoF officer said: "if we fail to remove the people from Mifimbo, then why should others stop fishing illegally?" (personal communication, September 30, 2011).

\section{Local representation and the illusion of community}

Yet it would be an over-simplification to attribute non-compliance solely to malfunctioning enforcement capacities. Within the FMP, the increase in illegal gear use and illegal fishing is linked directly to declining catch rates (Mölsä 2009). However they also admit that no systematic catch monitoring has taken place since the early 1990s. Illegal fishing is linked to decreased catches per unit, which can be as much a sign of increased competition as of biological overfishing. This article argues that Mweru-Luapula's fisheries management is based on not only a rationalist model of society - consisting of independent and economic agents - but also on a rationalist model of compliance and deterrence. This leads to a management analysis that goes as follows: if sanctions are higher than gains, compliance increases (Andrade and Midré 2011). This means that co-management - in the case of Mweru-Luapula - is merely used as a management tool aimed at increasing compliance with policy goals that are still created above the decentralized institutions. This argument is supported by the grievances of local community members who see the VMCs as nothing more than a long arm of the DoF, instead of regarding them as decentralized institutions with decision-making powers.

Although we believe the creation of co-management structures to be based on this underlying rationalist idea, it is too simple to ignore the complexities of local politics and power that affect issues of local legitimacy and representation. The latter is challenging to Mweru-Luapula's fisheries management.

Within PLARD, the local management committees strive to be a platform for a solid partnership between many different stakeholders (Mölsä 2009). Membership of the VMC board is obtained through local elections, which is a system that encourages community involvement. However, the current VMCs lack such adequate community representation. This is due to several reasons among which the aforementioned low popularity of such committees that are often seen as extensions of the DoF . In 2010 the VMC office in Kashikishi was even burned down. The main reason however seems to be the local electoral system itself, which favours the most respected community members (Fisheries Management Advisor, personal communication, September 26, 2011). This turns out to exclude certain community layers based on profession (e.g. the VMC of Nchelenge currently has no fishermen present), age, gender and origin. The latter is an important factor as certain species - like chisense - demand a high level of mobility from fishermen who therefore do not really belong to any community and lack representation in the VMCs. ${ }^{13}$ In fact, the electoral system is based on a false pretence of community. For instance, the national director of the DoF labels Mweru-Luapula's fishermen as indigenous, which moves right past above mentioned rural-urban linkages, the migration movement and fishermen's high mobility (Director DoF, personal communication, September 22, 2011).

The issue of unequal representation - e.g. practically all Nchelenge VMC members are elderly businessmen who grew up in Nchelenge - potentially challenges the co-management structure. As Svein Jentoft et al. (2009) posit:

Stakeholder groups possess unequal powers, for instance due to their privileged representation in the co-management regime. This means that some groups are capable of making their views more forcibly than others, in some instances even to the point that they can control the management system. (p. 30)

This potential threat is based upon the role of power. Every human social system is after all characterized by more and/or less powerful stakeholders. Amartya Sen (1981) describes this by means of his capabilities approach, where access to different assets - human, social, physical, financial, natural - defines one's wealth or poverty. This is never a static reality, but rather a dynamic process that constantly (re)creates and distributes access to assets through socioeconomic and political networks. Such networks are therefore essential and "carry power relations in both the patterns and processes of connection" (Goldman and Turner 2011, p. 215).

\footnotetext{
${ }^{12}$ For a further elaboration on the problem of policy enforcement in the Mifimbo breeding area, see Annear (2010).

${ }^{13}$ A study of Lwenya et al. (2008) on the impact of movement of fishermen on fisheries management in Kenya suggests that this is an issue that challenges decentralized fisheries management in general.
} 
The role of such networks has proven to be essential in Mweru-Luapula's fishing economy, as was illustrated by the credit and patron-client relations within both the colonial and postcolonial commercial fishery. The next section builds on the role of such networks within the current fishery. This is done by a fish chain analysis focusing on interactions between different economic stakeholders within the fishing economy. Such an analysis is useful to see how broader trends - like population pressure, growing investment and fluctuating fish prices - actually take place within a local setting. The works of Platteau $(1987,1989)$ on credit-relationships and the role of power in interactions between different agents - e.g. fishermen, fishmongers, fish traders - have proven to be an essential theoretical guideline for the following sections.

\section{Social change: the political ecology of inequality}

\section{Market, competition and the rationale of credit}

Mweru-Luapula's fisheries are characterized by a high number of artisanal fishers (Mölsä 2009). Although the nature of fishing has become more investment-driven, it is hard to analyze it in terms of a modernisation process at first glance. Small-scale organizational forms seem to persist. The nature of the fishery is still largely commercial - according to a PLARD survey, eighty-four percent of annual yield is sold - which makes the market a determining factor for Mweru's fishery. Price fluctuations - over the last years an increase in fish price has been observered - are therefore explained as much through decreasing catches per unit as through the large urban demand that - according to simple economics - results in price rises (Musumali et al. 2009). Within the FMP, this economic logic of the market is a mere context for the set-up of their program, which is focused on ensuring environmental sustainability. ${ }^{14}$ This section will, by focusing on economic relations between fishermen, dealers, processors and traders, analyze the economy of the market in depth.

A common view on the commercial nature of small-scale fisheries is of a system where private traders get involved directly only in the later stages of the marketing-processing fish chain (Platteau, 1989). This means that their only direct concern is the buying, transporting and selling of already caught and/or processed fish. Their involvement with the fishing itself is however often indirect, e.g. through credit-links. In fact this system is a blueprint for the 1970s and 1980s pale fishing economy that relied heavily on credit ties between large trade patrons and small-scale fishermen.

The rationale of credit has multiple origins, linked to the institutional set-up and the economic and ecological context. The nature of Mweru-Luapula as an allotrophic lake that relies heavily on meteorological conditions makes catch predictions highly uncertain. Credit ties therefore act as an insurance mechanism for both parties involved - the individual receiving credit and the person lending. For the fishermen, unpredictability of catches means a high variability of fishing income, which exposes them to substantial risk and uncertainty. Reciprocal credit can therefore function as a hunger insurance mechanism that reduces the risks of fishing and avoids disaster. The same uncertainty stimulates fish traders to establish such "credit-cum -marketing" relations that serve as an output-securing device, meaning that contractual relations that are more lasting are preferred over open market relations that are single-purpose and short-term arrangements. For the private traders this means that access to a stable supply of fish is guaranteed.

The context of credit relations in Mweru-Luapula is founded in a fear of losing income, rather than a desire to maximize gains. Regarding poverty, this means "it is scarcity and not sufficiency that makes people generous, since everybody is thereby insured against hunger" (Evans-Pritchard, cited in Platteau 2000: 468). On the other hand, credit-cum-marketing relations separate fishermen from market effects as well. Platteau and Abraham (1987) clarify that a stable source of credit makes fishermen forego possibilities to maximize incomes ("hidden interest"), for example by selling under the formal price which would have been set by the market ("hidden costs").

The nature of credit-relations in Mweru-Luapula's fishing economy depend - besides the allotrophic nature of the resource - on the type of fish species targeted as well. Within chisense fishing, labour-tying credit relations between gear owners and crewmen exist besides output-securing arrangements between traders, fishermen and aforementioned abakukungwisha (Chisense fisherman, personal communication, October 13, 2011). Chisense fishing depends heavily on peak operations during the year, while pale fishing is a somewhat more constant economic activity. Craft owners try to enlist dependable crewmen in advance of the season by using credit contracts - e.g. cash advances - involving a long-term commitment (mostly one fishing season). Quick and ready availability of labor is essential in chisense fishing.

As explained, credit relations were already present in the colonial fishery but proliferated from the 1970s onward. As Gordon (2003) explains:

\footnotetext{
${ }^{14}$ As a community facilitator in Nchelenge explained, this is indicated by the change in denomination of Mweru-Luapula from a "commercial fishing area" to a "fisheries management area" (personal communication, October 7, 2011).
} 
Patronage networks that rested on the distribution of goods in exchange for the promise of future labor remained a feature of the colonial and postcolonial economy through a new class of fish traders. Wealthy traders supplied fishers with nets and other goods and thereby created indebted dependents, who promised them their catch (p. 20).

Reasons for this were not only ecological or environmental, but stemmed from an institutional context as well. With the Zambian government losing grip on the Luapula valley in the 1970s, the formal credit market in the region collapsed. Government loans that had helped Mr. Kunda's fishing business were no longer available. Credit availability was therefore to be found within the fish chain itself. Informal money lenders did exist but they gradually disappeared (Businessman and former moneylender, personal communication, October 7, 2011). This is mainly due to the increasing mobility of fishermen that affected mutual trust to engage in money-lending activities. Credit relations based on networks of family and kinship do exist as well, but these function more as a support mechanism than an economic alliance. Yet their role can not be underestimated, as most respondents in this research at one time or other relied on financial aid from friends or relatives who provided them with money. Above mentioned credit-cum-marketing and credit-cum-labour arrangements are thus the outcome of imperfections in - and even the absence of - alternative sources of credit as well. ${ }^{15}$ In general, this article argues that market imperfections (unequal flow of information, lack of infrastructure and access to capital and market) and the ecological set-up of the fishery in Mweru-Luapula have stimulated the development of credit contracts aimed at reducing transactions costs (Overå 2003).

\section{The irrationality of credit}

Those labor and output-tied credit arrangements within the fishing economy do not only act as an indicator for growing economic competition, uncertainty and institutional change. Although small-scale organizational forms of fishing persist, they are incorporated within a larger economic system, which affects traditional production relations. The credit arrangements do not only function as a mutual insurance mechanism. The economic alliances that originate through such contractual arrangements also channel market preferences, e.g. popularity of salted and dry fish, to the local fishermen. Furthermore these financial bonds to a great extent affect the local markets on the shores of Lake Mweru, because less fish is being sold to local merchants.

The role of power is essential in describing credit arrangements in Mweru-Luapula, where subordination and marginalisation are present. Credit is an informal insurance mechanism for both parties but it also involves negative dependencies. Fishing catches depend not only on competence but also on luck (Platteau, 1989). A bad fishing season can lead to indebtedness for fishermen, which can result in a loss or selling of assets. This is a risk peculiar to credit arrangements with (semi-) urban traders: they can be mutually beneficial but the hazards are bigger for the debtor. Moreover not every fisherman is able to obtain credit. In remote areas like the fishing islands in Lake Mweru, the presence of fish traders can be very limited, which means less competition between traders hence less incentive for those traders to establish credit-cummarketing relations. ${ }^{16}$ Consequently it is more difficult for the fishermen on these islands to gather capital to purchase fishing nets and boats. These unequal opportunities also exist on the other marketing side of the fish chain. More locally based fish traders are generally less well provided with capital. They even have to delay payment to fishermen until they have sold the fish themselves. This reverses in fact such credit-cummarketing arrangements. Fishermen therefore usually prefer urban and more large-scale fish traders over local dealers.

\section{Coping with moral hazard: from the emergence of a new class...}

Mweru-Luapula's fisheries have evolved notably over the last decades. This has challenged credit-cummarketing relations between large-scale traders and fishermen to a point that they are almost non-existent nowadays on Mweru's shoreline. There are several reasons for this. Firstly improvement of road infrastructure and the introduction of mobile phones has improved regional integration of fishermen and especially increased their mobility. For large-scale dealers this is risky because possibilities of free-riding by fishermen grow as a consequence. This increases costs of business transactions - and makes them more risky - for the traders. Such an evolution is further strengthened by a growing competition between the traders as well. Platteau (1989) points to risks of "moral hazard," meaning that external fish traders are not in a good position to assess the trustworthiness of producers, to establish social bonds with them or to pressure them.

\footnotetext{
${ }^{15}$ Credit institutions - like Bayport and Natsave - do exist in Mweru-Luapula, but they only provide capital to payrollbased workers like government officials and civil servants. They do however transfer money (e.g. for over 800 households in Nchelenge), meaning that the organization does play a part in credit relations between stakeholders in the fishing economy (Nchelenge Bayport employee, personal communication, October 4, 2011).

${ }^{16}$ Yet such networks can become necessary when a local monopsony or oligopsony has to be protected from newly arrived traders. This applies for example to a group of Congolese traders near Mununga, between Chiengi and Kashikishi, who are nowadays using strong credit arrangements to protect their turnover (Congolese fisherman-trader and businessman, personal communication, October 7, 2011)
} 
These risks of moral hazard have only increased over the last decades, to a point where large-scale traders have had to change their strategies. A class of local intermediaries between fishers and traders came into being. They are referred to as abanamakupwila, i.e. female fish traders who act as middlepersons between fishermen, local consumers and large-scale fish traders. These petty (headload) traders can generally be considered as "autochthonous", meaning that their relations with fishermen are often founded on ties of caste, residence, kinship and custom (Platteau, 1989). Although these relations are very important, they are mostly beneficial in addition to credit-relations. Competition between these abanamakupwila is very high, so provision of credit - mostly through cash-in-advance arrangements for one bucket of raw fish - and even fishfor-sex arrangements with fishermen are not exceptional (Annear 2010; Béné and Merton 2008; female fishmonger, personal communication, September 30, 2011). It can be observed, that when the fishermen arrive on shore, these female traders rush towards their boats to be the first to buy fish. Intensive discussion and conflict between them is a usual consequence. The advantages of pre-made arrangements are therefore easy to see.

The existence and origin of abanamakupwila is ambiguous. On the one hand their presence secures a certain supply of fish for the local communities surrounding the lake. On the other hand they act as a necessary go-between for large-scale fish dealers with no local background. For many large-scale dealers it is safer to make arrangements with these local female intermediaries because they usually buy, process and sell their fish at the same local market. Yet it is also more expensive. Huge competition between the female fishmongers makes them raise their bids as well, which consequently affects the people buying from them. Therefore, fish merchants increasingly try to circumvent these middle (wo)men. One strategy is "employing" a female trader, e.g. through marriage, or establishing social bonds with them. This can pressure prices down - even level it out in case of marriage - or ensure a stable supply, because all abanamakupwila respondents admitted they prefer selling their fish stock to familiar or friendly traders (Abanamakupwila, personal communication, September 29, 30 and October 12, 2011). Yet another tactic consists of competing directly with these female fishmongers, by buying directly from the fishermen on the lake. ${ }^{17}$ This "price competition" affects these female traders to a great extent and even influences food security around Lake Mweru. As many are no longer able to afford full-grown fish, alternatives have to be sought. As one respondent mentioned, "local people rather buy beef because it is cheaper now" (Chisense fisherman, personal communication, October 13, 2011). Even more, local preference for cheap fish is being channeled through the abanamakupwila to the fishermen. This stimulates the targeting of juvenile fish - also known as icibalebale which is sold by these female traders in the local markets of the villages surrounding Lake Mweru. Illegal fishing methods are therefore not only an outcome of competition between fishermen. It is driven by the local merchants to secure a source of income and in general by households in nearby villages who can no longer afford to buy adult pale or breams.

\section{...to its elimination: the vertical integration of large-scale dealers}

Generally, connections between large-scale dealers, local intermediaries and fishermen are not reliable. One day fishermen may prefer to sell to external traders for a better price: the next day they can promise to supply local traders related to them by kinship or custom. Transaction costs are therefore high. This is currently stimulating these urban traders to enter the production phase of fishing themselves, instead of intervening at the processing or marketing phase. This has led to the observation that many individuals are now combining fishing and trading activities. It is important to understand that this is a process of vertical integration instigated by the traders themselves, and not an expansion of occupation by the fishermen. Within the fish chain it is thus an evolution moving top-down and not bottom-up. In order to obtain sufficient supply, it is more profitable for the traders to invest in fishing boats and nets and to employ fishermen than to buy from them. This vertical integration affects traditional production relations. Historically relations between crew members and gear owners rested on family ties or kinship, but now more formal and contractual production relations - like in the chisense fishing economy - are emerging. This means that a fishing boat is now considered as individual property, rather than an instrument of cooperative labour (Platteau 1989).

The proliferation of leleke fishing on Lake Mweru is a manifest illustration of this. Leleke fishing entails a manner of open water fishing and processing by means of anchor boats, called ifyombo. From these boats, the fish are sold to urban markets in the Copperbelt, Lubumbashi and Lusaka. The boats are also used as bases for sleeping and cooking for the fishermen, who stay on the lake for months. The ifyombo on the Zambian side of Lake Mweru are owned by both Zambian and Congolese businessmen-traders, while most of the "fish laborers" on the ifyombo are Congolese. The anchor boats are usually guarded by attendants who see to it that no fish are stolen from the vessel owner. Fishermen are paid fifty per cent of the catch per boat. Their relationship with the owner-trader is purely businesslike, but certainly not on an equal footing. Living circumstances on the ifyombo boats are harsh: twenty to thirty fishermen have to live on a vessel not larger than thirty square meters, without any sanitary facilities. Outbreaks of cholera are not uncommon. Moreover ifyombo are usually not well built or maintained. This cost forty Zambian and Congolese lives in March 2011

\footnotetext{
${ }^{17}$ This strategy was actually introduced by the Governor of Katanga - who combines political and business activities - in the 1990s. He used speedboats on the lake to buy directly from the fishermen.
} 
(Online Article Zambian Watchdog, March 2 2011; Online Article Lusaka Times, March 3 2011). Since the implementation of the Fisheries Management Plan has started, leleke fishing is now formally prohibited, because of its semi-industrial nature - more than a thousand nets are employed to provide one anchor boat with fish. Yet, current patrolling units only target the illegal Congolese fishermen-employees while the ifyombo owners remain unaffected. One can easily observe that leleke fishing - as it currently takes place contains strong mechanisms of subordination and marginalisation.

The vertical integration of large-scale traders further threatens the position of the small female headload traders, as a large quantity of fish moves directly past traditional landing sites towards the urban markets. The absence of reliable statistics on this "invisible" fishing economy is problematic as it challenges any specific environmental and developmental management policy. The FMP does plan on installing fixed landing sites to control price proliferation, but it is questionable that this policy will end the invisible and illegal trade.

To summarize, the increasing vertical integration into fisheries production phase of private traders resulted from problems on the supply side, reinforced by risks of moral hazard and high prices. Logically this increases overall fishing effort. As one Congolese large-scale fish traders and gear owner explained, if supply was sufficient and more affordable, vertical integration would stop (personal communication, October 7 , 2011). He even stated that "the more fish we have in the lake, the less fishermen would be involved". From a deductive point of view one can understand this thought, yet it is almost certain that demand will always surpass supply in Mweru-Luapula's fishery, making it highly unlikely that fishing effort will decrease.

\section{Assessing inequality: witchcraft and the defense of a moral community}

If one places the - often told - story of reduced catch that threatens livelihoods for small-scale fishermen and local traders next to this process of vertical integration - comprising capital investment in fishing gear, units and crew members - one can notice that Mweru-Luapula's fishing economy still offers opportunity alongside vulnerability. The narrative of a collapsed commercial economy - exemplified by the remnants of former ice plants in Nchelenge and Kashikishi - is simultaneously contradicted by the initiative of a Congolese trader-owner who has started to build his own ice plant for transport to the urban markets (personal communication, October 7, 2011). Even more, the contrast between the most impoverished and vulnerable households and the elite, such as the Congolese trader, has grown.

Currently no study offers quantifiable data to prove this emerging inequality, yet one interesting indicator does exist. It is found in the rapid increase in witchcraft accusations, an observation that I believe should be treated as a sort of social diagnostic. This is not just a local phenomenon. In recent years, research in Africa has reported an ongoing increase in witchcraft and sorcery accusations (Moore and Sanders 2001). One can relate this to expanding opportunities for socioeconomic upward mobility and local responses to this. This is excellently described by Moore and Sanders (2001:18): "popular beliefs about witchcraft are seen as a form of political action from below, where witchcraft accusations are used as levelling mechanisms preventing social inequalities from developing beyond the point of community control." ${ }^{18}$ The connection between wealth accumulation and witchcraft has been elaborated extensively (Moore and Sanders 2001). Exposure to market economics and capitalist entrepreneurship has created possibilities for wealth accumulation that lie beyond community control. Responses to these changes in wealth distribution, by means of witchcraft accusations, function as a defense of a "moral community", based on feelings of economic justice and responsibility (Gordon 2006). Yet research interprets witchcraft accusations as a social response to change rather than as a desire for a past moral order. Witchcraft accusations in Mweru-Luapula have historically been a symptom of change: the disappearance of mpumbu made African fishers accuse European fishermen of using witchcraft, the arrival of urban chisense fishermen was - and still is - accompanied by a cultural idiom that insinuates only sorcerers catch chisense (Gordon 2006; chisense fisherman, personal communication, October 13, 2011). Changes in wealth and its distribution are explained through such narratives using witchcraft and invented traditions.

In Nchelenge and Kashikishi, where this research took place, the current relevance of bad magic and sorcery was confirmed by all respondents - i.e. fishermen, small-scale traders, abanamakupwila, urban traders and institutional as well as traditional legal authorities. The role of the latter is in fact interesting and possibly challenging for the fisheries co-management regime. As chiefs and village headmen use witchdoctors to verify if one is practicing bad sorcery, government policy sees witchcraft accusations as a legal offence (Village headman Nchelenge, September 30 2011; Chief Kambwali, personal communication, October 12, 2011; Police officer, personal communication, October 5, 2011). This exposes an ambivalent relationship between the state and culture or tradition, invented or not. It is also capable of creating the perception that the state - by outlawing witchcraft - tries to sustain social inequality and protect those who allegedly used sorcery for their own enrichment (Moore and Sanders 2001). The inclusion of these two legal approaches to witchcraft in the co-management structure may prove to be restrictive for the enforcement of fisheries policy.

${ }^{18}$ Ferguson (1999) notices that witchcraft or sorcery is also a form of violence. Besides growing accusations as a community response, social advancement is in fact at times sought through nefarious practices such as poisoning or murder. Furthermore witchcraft accusations also result from a sense of injustice regarding people's own misfortunes. 


\section{Conclusion: closing the gap}

Throughout the entire production chain - from the ecological environment to harvest and post-harvest processes - one can find challenges to fisheries as well as opportunities to improve fisheries governance (Chuenpagdee and Jentoft 2011). An intersection approach regarding fisheries management should therefore be properly examined and understood, rather than merely focusing on the bio-physical environment and the harvest system.

Social and economic relations between actors within this fish chain contain aspects of power, whereby processes of subordination and marginalization occur. The use of credit arrangements is crucial in this. Indebtedness to middlepersons or traders may drive fishermen to use destructive fishing methods to increase catches, in their turn damaging fishing habitats and overall productivity. Moreover, demand for juvenile fish by households seeking a cheap supply of food is channeled through such economic networks. A management policy that focuses heavily on the MCS of IUU fishing moves, therefore, right past these social and economic constraints - and incentives - that lead to illegal fishing. One can regard the removal of illegal fishers by patrolling as mowing the lawn: it does not prevent the grass from growing back. In other words it is a simplistic to approach compliance merely as proportionally connected to enforcement capacity.

This article has attempted to confront the environmental knowledge base - that constitutes the current management system - with a relational and historical perspective on the social and economic fisheries system. As mentioned, the vision of the FMP relates the open-access nature of Lake Mweru to population, resource availability and poverty. This perspective is relational only in the sense that stakeholders' wealth or poverty are directly related to the quantity of fish in the Lake and lagoons. From both a historical and a contemporary analysis of the political ecology of Mweru-Luapula's fishery, it can be questioned whether poverty is a distributional problem rather than a consequence or cause of overfishing. It is essential to see how power works in small-scale fisheries: it is an instrument that defines socioeconomic relations in Mweru-Luapula and determines distribution of benefits and losses. No fisheries system is characterized by equal and independent agents whose wealth or poverty depends only on the amount of fish they catch, process or market: "one needs to be sensitive to the fact that one group may draw benefits from the other in ways that indicate subordination and marginalisation" (Jentoft and Midré 2011: 47). The relational perspective on fisheries taught us that growing competition throughout the whole fish chain has modified traditional production relations to an extent that inequality only increases. This "penetration of capital" - as Platteau (1989) described, is a vital factor in the creation and recreation of wealth and poverty (Bavinck 2011). Briefly worded, the analysis of the political economy of exploitation and dependence illustrates that changing production relations due to growing competition - caused by the "predatory incursion of open-access capitalism" - instigates and sustains processes of marginalisation, exclusion and subordination, which only increase inequality. ${ }^{19}$

These insights not only expose superficialities in policy priorities of Mweru-Luapula's fisheries management: they also challenge co-management itself. As power is essential in the social fisheries system, it is important to see how power works in co-management (Jentoft 2007). As Jentoft and Midré (2011:50) elucidate, "co-management is about restructuring relationships between user-groups and government authorities to facilitate commitment and mobilise resources and interactive learning. Co-management arrangements are about creating action space and about providing the individual and collective capabilities that users need in order to fill it.". In Mweru-Luapula's fishery, this political action space for fishermen, traders and other agents is not a static but a competitive space where confrontations between stakeholders occur. For example, the removal of the abanamakupwila is an item on the agenda of the local co-management institutions as well as the Mweru-Luapula Fishing Association (FA chairman, personal communication, October 6, 2011). Their exclusion will benefit large-scale traders but cause harm to local markets and smallscale fishermen who sell their fish exclusively to these middlepersons. Co-management arrangements therefore often do notbenefit the poor, but rather those who are already better off. In the context of inequality, more powerful users will always try to renegotiate institutional regulations in their favour (Haller and Merten 2008).

This research argues that institutional governance in fisheries development should always be built upon, or start from, the many dimensions (social, ecological, political, economic) of a fishery system that is shaped not only locally but through a constant interaction with external factors - acting as both threats and opportunities. It is necessary to close the gap between locally based understandings, policy and legislation. Too often conventional management is based on general paradigms regarding common-property theory and shared resources. This one-size-fits-all approach characterizes a lot of small-scale fisheries management programs in the global South (Hauck 2011). This article therefore argues for a differentiation process in the global management of small-scale fisheries.

\footnotetext{
${ }^{19}$ Keil (1998): open-access capitalism refers to the lack of regulation and restriction in capitalist undertakings in fisheries, not to an open-access nature of the fisheries resource itself.
} 


\section{References}

Agrawal, A. 2005. Environmentality: technologies of government and the making of subjects. Durham, N.C.: Duke University Press.

Andrade, H. and G. Midré. 2011. The merits of consensus: small-scale fisheries as a livelihood buffer in Livingston, Guatemala. In S. Jentoft and A. Eide (eds.) Poverty mosaics: realities and prospects in small-scale fisheries. Springer Netherlands. Pp 427-449.

Andrew, N. and L. Evans. 2009. Approaches and frameworks for management and research in small-scale fisheries in the developing world. The WorldFish Center Working Paper 1914. Penang, Malaysia: The WorldFish Center.

Andrew, N. and L. Evans. 2011. Diagnosis and the management constituency of small-scale fisheries. In R.S. Pomeroy and N. Andrew (eds.). Small-Scale fisheries management: frameworks and approaches for the developing world. Wallingford, Oxfordshire: CAB International. Pp 35-58.

Annear, C.M. 2009. Navigating constricted channels. local cooption, coercion, and concentration under comanagement, Mweru-Luapula Fishery, Zambia. Journal of Political Ecology 16: 34-38.

Annear, C.M. 2010. Weathering the commons: resilience and heterogeneity in an inland fishery, MweruLuapula, Zambia. Unpublished doctoral dissertation: Boston University Graduate School of Arts and Sciences.

Bavinck, M. 2011. Wealth, poverty and immigration: the role of institutions in the fisheries of Tamil Nadu, India. In S. Jentoft and A. Eide (eds.). Poverty mosaics: realities and prospects in small-scale fisheries. Springer Netherlands, Pp173-194.

Béné, C. 2003. When fishery rhymes with poverty: a first step beyond the old paradigm on poverty in smallscale fisheries. World Development 31(6): 949-975.

Béné, C. 2009. Are fishers poor or vulnerable? Assessing economic vulnerability in small-scale fishing communities. Journal of Development Studies 45(6): 911-933.

Béné, C. and S. Merton. 2008. Women and fish-for-sex: transactional sex, HIV/AIDS and gender in African fisheries. World Development 36(5): 875-899.

Brown, J.C. and M. Purcell. 2005. There is nothing inherent about scale: political ecology, the local trap, and the politics of development in the Brazilian Amazon. Geoforum 36: 607-624.

Chuenpagdee, R. and S. Jentoft. 2011. Situating poverty: a chain analysis of small-scale fisheries. In S. Jentoft and A. Eide (eds.). Poverty mosaics: realities and prospects in small-scale fisheries. Springer Netherlands, Pp27-42.

Cinner, J.E., Daw T. and T.R. McClanahan. 2008. Socioeconomic factors that affect artisanal fishers' readiness to exit a declining fishery. Conservation Biology 23(1): 124-130.

Ensminger, J. 1992. Making a market: the institutional transformation of an African society, Cambridge: Cambridge University Press.

Ferguson, J. 1999. Expectations of modernity: myths and meaning of urban life on the Zambian Copperbelt. California: University of California Press.

Goldman, M.J. and M.D. Turner. 2011. Introduction. In M.J. Goldman, P. Nadasdy and M.D. Turner, Knowing nature: conversations at the intersection of political ecology and science studies. Chicago: University of Chicago Press. Pp1-24.

Gordon, D. 2005. Growth without capital: a renascent fishery in Zambia and Katanga. Journal of Southern African Studies 31(3): 495-511.

Gordon, D. 2006. Nachituti's gift: economy, society and environment in Central Africa. Madison: The University of Wisconsin Press.

Gordon, H.S. 1954. The economic theory of a common-property resource: the fishery. Journal of Political Economy 62(2): 124-142.

Haller, T. 2007. The contested floodplain: institutional change of common pool resource management and conflicts among the Ila, Tonga and Batwa, Kafue Flats (Southern Province), Zambia. Post-doctoral dissertation. University of Zurich: Department of Social Anthropology.

Haller, T. and S. Merten. 2008. "We are Zambians - don't tell us how to fish!" Institutional change, power relations and conflicts in the Kafue Flats fisheries in Zambia. Human Ecology 36: 699-715.

Hauck, M. 2011. Small-scale fisheries compliance: integrating social justice, legitimacy and deterrence. In R.S. Pomeroy and N. Andrew (eds.), small-scale fisheries management: frameworks and approaches for the developing world. Wallingford, Oxfordshire: CAB International. Pp196-215.

Hardin, G. 1968. The tragedy of the commons. Science 162: 12433-12438.

Islam, M.M. 2011. Living on the margin. the poverty-vulnerability nexus in the small-scale fisheries of Bangladesh. In S. Jentoft and A. Eide (eds.). Poverty mosaics: realities and prospects in small-scale fisheries. Springer Netherlands. Pp71-96.

Jentoft, S. 2007. In the power of power. the understated aspect of fisheries and coastal management. Human Organization 66: 426-437. 
Jentoft, S., M. Bavinck, D.S. Johnson, and K.T. Thomson. 2009. Fisheries co-management and legal pluralism: how an analytical problem becomes an institutional one. Human Organization 68(1): 27-38.

Jentoft, S. and G. Midré. 2011. The meaning of poverty: conceptual issues in small-scale fisheries research. In S. Jentoft and A. Eide (eds.). Poverty mosaics: realities and prospects in small-scale fisheries. Springer Netherlands. Pp43-70.

Jul-Larsen, E. and P.A.M. Van Zwieten. 2002. African freshwater fisheries: what needs to be managed? World Fish Center Quarterly 25(3\&4): 35-40.

Jul-Larsen, E. 2003. Analysis of effort dynamics in the Zambian inshore fisheries of Lake Kariba. In E. JulLarsen, J. Kolding, R. Overa, J.R. Nielsen, and P.AM. Van Zwieten (eds.) Management, co-management or no management? Major dilemmas in Southern African freshwater fisheries. Synthesis Report. FAO Fisheries Technical Paper, 426/2: 233-232.

Kapasa, C., I. Malasha, and D.C. Wilson. 2005. Experience based knowledge and fisheries management in the Mweru-Luapula System. The final report of the knowledge in fisheries management project. Annex 11. Brussels: Research Directorate General.

Kooiman, J., M. Bavinck,S. Jentoft, and R. Pullin (eds.), 2005. Fish for life: interactive governance for fisheries. Amsterdam University Press.

Kraan, M. 2011. More than income alone: the anglo-ewe beach seine fishery in Ghana, In Jentoft, S. and A. Eide (eds.). Poverty mosaics: realities and prospects in small-scale fisheries. Springer Netherlands. Pp 147-172.

Lwenya, C., Y. Ernest, R. Abila, and N. Fiona. 2009. The impacts of the movement of fishers on the fisheries management in Lake Victoria, Kenya. Conference paper, $13^{\text {th }}$ Conference Wuhan 2009. Edgbaston, Birmingham: University of Birmingham.

Malasha, I. 2003. Colonial and postcolonial fisheries regulations: the cases of Zambia and Zimbabwe. In. JulLarsen, E,, J. Kolding, R. Overa, J.R. Nielsen, and P.AM. Van Zwieten (eds.) Management, comanagement or no management? Major dilemmas in Southern African freshwater fisheries. Synthesis Report. FAO Fisheries Technical Paper, 426/2: 253-266.

Malasha, I. 2007. The governance of small scale fisheries in Zambia. Research project on food security and poverty alleviation through improved valuation and governance of river fisheries. Lusaka, Zambia: WorldFish Center.

Mölsä, H. 2009. Fisheries management plan for Mweru-Luapula, Zambia. Programme for Luapula Agricultural and Rural Development.

Moore, H.L., and T. Sanders (eds.). 2001. Magical interpretations, material realities: modernity, witchcraft and the occult in postcolonial Africa. London: Routledge.

Musambachime, M.C. 1995. The role of Kasenga (Eastern Shaba) in the development of Mweru-Luapula Fishery. African Studies Review 38(1): 51-68.

Musumali, M., S. Heck, S.M.C. Husken, and M. Wishart. 2009. Fisheries in Zambia: an undervalued contributor to poverty reduction. World Fish Center \& World Bank Policy Brief 1913, Lusaka, Zambia: WorldFish Center..

Nugent, P. 2004. Africa since independence. a comparative history. New York: Palgrave Macmillan.

Onyango, P.O. 2011. Occupation of last resort? Small-scale fishing in Lake Victoria, Tanzania. In S. Jentoft and A. Eide (eds.) Poverty mosaics: realities and prospects in small-scale fisheries. Springer Netherlands. Pp 97-124.

Ostrom, E. 1990. Governing the commons: the evolution of institutions for collective Action. Cambridge: Cambridge University Press.

Overå, R. 2003. Market development and investment "bottlenecks" in the fisheries of Lake Kariba, Zambia. In E. Jul-Larsen, J. Kolding, R. Overa, J.R. Nielsen, and P.AM. Van Zwieten (Eds.) Management, comanagement or no management? Major dilemmas in Southern African freshwater fisheries, Synthesis Report. FAO Fisheries Technical Paper, 426/2: 201-232.

Platteau, J-P and A. Abraham. 1987. An inquiry into quasi-credit contracts: the role of reciprocal credit and interlinked deals in small-scale fishing communities. Journal of Development Studies 23(4): 461-490.

Platteau, J-P. 1989. Penetration of capitalism and persistence of small-scale organizational forms in third world fisheries. Development and Change 20: 621-651.

Platteau, J-P. 2000. Institutions, social norms, and economic development. Harwood Academic Publishers.

Pomeroy, P.S., J.E. Cinner and J. Raekjaer. 2011. Conditions for successful co-management: lessons learned in Asia, Africa, the Pacific and the Wider Caribbean, In R.S. Pomeroy and N. Andrew (eds.) Small-scale fisheries management: frameworks and approaches for the developing world. Wallingford, Oxfordshire: CAB International. Pp 115-131.

Sen, A. 1981. Poverty and famines. Oxford: Clarendon Press.

Smith, L., K. S. Nguyen and K. Lorenzen. 2005. Livelihood functions of inland fisheries: policy implications in developing countries. Water Policy 7: 359-383. 
Walker, P.A. 2005. Political ecology: where is the ecology? Progress in Human Geography 29(1): 73-82.

Wilson, D.C., M. Ahmed, A. Delaney, S. Donda, C.K. Kapasa, I. Malasha, K. Muyangali, F. NjayaT. Olesen, E. Poiosse and J. Raakjaer. 2010. Power and politics in fisheries co-management. programmes in Southern Africa. Report Innovative Fisheries Management Publication 224: Aalborg: Aalborg University.

Van Zwieten, P.A.M., P.C. Goudswaard, and C.K. Kapasa. 2003. Mweru-Luapula is an open exit fishery where a highly dynamic population of fishermen makes use of a resilient resource base. In E. Jul-Larsen, J. Kolding, R. Overa, J.R. Nielsen, and P.AM. Van Zwieten (eds.) Management, co-management or no management? Major dilemmas in Southern African freshwater fisheries. FAO Fisheries Technical Paper, 426/2: 1-33.

\section{Legal Documents}

UNFCCC. 2010. Clean Development Mechanism Projects Website. [accessed March 12 2010]. www.cdm.unfccc.int.

Fisheries Act, 1974 (Cap. 200). [accessed August 112011

http://www.ecolex.org/ecolex/ledge/view/RecordDetails;jsessionid=14DC823330BA9B2C19AF60997F038F E1?id=LEX-FAOC002257andindex=documents

Fisheries Amendment Act, 2007 (Nr. 22 of 2007). [accessed August 11 2011]

http://www.ecolex.org/ecolex/ledge/view/RecordDetails;DIDPFDSIjsessionid=673D8C5A73342116F443653 3F5673B96?id=LEX-FAOC078316\&index=documents

Fisheries Act 2011. [accessed August 112011 ]

http://www.parliament.gov.zm/index.php?option=com_docmanandtask=cat_viewandgid=153andlimit=5andli $\underline{\text { mitstart}=15 \text { andorder=hitsanddir=DESC }}$

Local Government Act 2004 (Cap. 281). Retrieved from Southern African Legal Information Institute (SAFLII).

http://www.saflii.org/zm/legis/consol_act/lga182/

\section{Newspaper Articles}

About 40 fishermen die in Lake Mweru storm (2011, March 2). Retrieved from http://www.zambianwatchdog.com/2011/03/02/about-40-fishermen-die-in-lake-mweru-storm/ on April 2, 2012

ZNBC, Lake Mweru tragedy: Eight managed to swim to safety (2011, March 3). Retrieved from http://www.lusakatimes.com/2011/03/03/lake-mweru-tragedy-managed-swim-safety/ on April 2, 2012 


\section{Selected interviews by the author}

Bayport Employee, Nchelenge, October 4, 2011

Chairman Mweru-Luapula Fishing Association, Kashikishi, October 6, 2011

Chairman Nchelenge District Art Advisory Committee, October 6, 2011

Chieftainess Kambwali, Kambwali, October 19, 2011

Chisense fishermen, Nchelenge, October 13, 2011

Community facilitator Kilwa Island, Nchelenge, October 4, 2011

Congolese businessman-fish trader, Kashikishi, October 7, 2011

Court Interpreter Nchelenge, Nchelenge, October 12, 2011

District Planner Officer Nchelenge, Nchelenge, October 12

Executive Officer Village Committee Nchelenge, Nchelenge, September 30, 2011

Female local traders, Nchelenge, September 29, 30 and October 12, 2011

Fishermen,

- Kashikishi, October 6, 8 and 9, 2011

- Nchelenge, September 29, 30, 2011

Immigration Officer Nchelenge, October 29, 2011

Officer for Cultural Affairs Nchelenge, Nchelenge, September 29, 2011

Officer Department of Fisheries Nchelenge, Nchelenge, September 30, 2011

Prison Officer Nchelenge, Nchelenge, October 12, 2011

Shop owner and Fish trader Nchelenge and Kashikishi, Nchelenge, October 4, 2011

Station Inspector Police Department Nchelenge, Nchelenge, October 3, 2011

Village headman Nchelenge, Nchelenge, September 30, 2011

VMC Chairman

- Kashikishi, Kashikishi, October 6, 2011

- Nchelenge, Nchelenge, October 5, 2011

Workers Ice Plant "Food Enterprise", Nchelenge, October 13, 2011

World Vision Officer Nchelenge, Nchelenge, October 13, 2011

Zambian Government Refugees Officer, Lusaka, September 21, 2011

National Director for Department of Fisheries Zambia, Lusaka, September 22, 2011

Operations and Repatriation Officer Zambia, Lusaka, September 21, 2011

Fisheries Management Advisor Luapula Province, Mansa, September 26, 2011 


\begin{abstract}
This paper starts from the perspective that resource management approaches are based upon a body of environmental knowledge. By analysing fisheries management in Mweru-Luapula, Zambia, I argue that this body of environmental knowledge has 1) remained largely unchanged throughout the recent shift to comanagement and 2) is to a great extent based upon general paradigmatic conventions with regard to common property regimes. The article outlines the historical trajectories of both resource management and the political ecology of Mweru-Luapula's fishing economy. Using a relational perspective - by looking at interaction of the local fishing economy with external developments, but also by examining socioeconomic relations between individual actors - this article exposes constraints and incentives within the local fishing economy that are not absorbed in the current co-management regime. These findings challenge both policy goals and community-based resource management itself. I argue that governance of small-scale fisheries - in order to close the gap between locally based understandings, policy and legislation - should always be built upon all dimensions (social, economic, ecological, and political) that define a fisheries system.
\end{abstract}

Keywords: co-management, common-property resource management, political ecology, Mweru-Luapula fishery, Zambia.

\title{
Résumé
}

Cet article commence à partir du point de vue que les approches de gestion des ressources sont fondées sur la connaissance de l'environnement. En analysant la gestion des pêches dans le lac Mweru-Luapula, en Zambie, je soutiens que ce corps de connaissances sur l'environnement 1) est resté pratiquement inchangé tout au long de l'adoption récente de la co-gestion de la pêche; 2) est basée sur des conventions générales paradigmatiques de régimes de propriété commune. L'article décrit les trajectoires historiques de la gestion des ressources et de l'écologie politique de l'économie de la pêche dans le lac Mweru-Luapula. L'utilisation d'un point de vue relationnel - en examinant l'interaction de l'économie locale de la pêche avec des événements extérieurs, mais aussi les relations socio-économiques entre les acteurs individuels - cet article expose les contraintes et les incitations au sein de l'économie locale de la pêche qui ne sont pas absorbés dans le régime courant de cogestion. Ces résultats remettent en question les objectifs politiques. Ils contestent également l'approche communautaire de gestion des ressources. Je soutiens que la gouvernance de la pêche artisanale - afin de combler le fossé entre la connaissance, la politique et la législation locale - doit toujours se fonder sur toutes les dimensions qui définissent un système de pêche (social, économique, écologique et politique).

Mots-clés: co-gestion, gestion des ressources de propriété commune, l'écologie politique, la pêche MweruLuapula. la Zambie.

\section{Resumen}

Este artículo comienza desde la perspectiva de acercamientos a la gestión de recursos basados en un cuerpo de conocimiento medioambiental. Mediante un análisis de la gestión de la pesca en Mweru-Luapula, Zambia, argüimos que este cuerpo de conocimiento medioambiental 1) no ha variado en el cambio reciente hacia la cogestión y 2) está basado en gran medida en convenciones paradigmáticas con respecto a regímenes de propiedad común. Por tanto, estudiamos simultáneamente las trayectorias históricas de la gestión de recursos y la ecología política de la economía pesquera de Mweru-Luapula. Usando una perspectiva relacional (mediante la observación de la interacción de la economía pesquera local con desarrollos externos, pero examinando también las relaciones socioeconómicas entre actores individuales) este estudio expone las restricciones y los incentivos dentro de la economía pesquera local que no son absorbidos en el actual régimen de cogestión. Estas conclusiones cuestionan tanto las metas de las políticas seguidas como la propia gestión de recursos comunitaria. Argüimos por tanto que la gobernanza de zonas de pesca de pequeña escala -a fin de disminuir los huecos entre los entendimientos, política y legislación locales- deberían construirse siempre sobre la base de todas las dimensiones que definen un sistema pesquero (social, económico, ecológico y político)

Palabras clave: cogestión, gestión de recursos de propiedades comunitarias, ecología política, pesca, MweruLuapula, Zambia. 